УДК 78.01/783:2-53

DOI 10.31723/2524-0447-2018-26-135-148

Кристина Олеговна Дяблова

https://orcid.org/0000-0002-7740-4527

аспирантка кафедры истории музыки

и музыкальной этнографии

ОНМА имени. А. В. Неждановой odma_n@ukr.net

\title{
ОСОБЕННОСТИ СЛУЖБЫ ПРЕОБРАЖЕНИЯ В ВОСТОЧНОСЛАВЯНСКОЙ ПЕВЧЕСКОЙ ПРАВОСЛАВНОЙ ТРАДИЦИИ КОНЦА XIV - ПЕРВОЙ ПОЛОВИНЫ XV СТОЛЕТИЯ В КОНТЕКСТЕ СМЕНЫ ЦЕРКОВНЫХ УСТАВОВ
}

Цель исследования - на основе анализа восточнославянских богослужебных и певческих рукописных источников конца XIV - первой половины XV столетия выявить эволюционные процессы певческой части православной службы Преображения в переходный период смены иерковных уставов (Студийский/Иерусалимский). Методология исследования - опора на источниковедческий метод с иелью поиска источников указанного периода; палеографический метод для уточнения датировки кодексов, исследования способов их вербальной и певческой фиксации; компаративное и текстологическое изучение ряда песнопений праздника Преображения, зафиксированных в восточнославянских певческих рукописях. Научная новизна состоит в том, что впервые преображенский певческий цикл православной восточнославянской традиции рассматривается в контексте смены Студийского устава на Иерусалимский на основе комплексного анализа музыкальной медиевистики. Выводы. Исследование ряда восточнославянских средневековых кодексов переходного времени, выявленных автором работы, показало: 1. отличие богослужебных уставов от певческих рукописей указанного периода; 2. наличие двух репрезентативных певческих списков первой половины XVвека; 3. анализ репертуарно-жсанровых и текстологических аспектов службы праздника показал существенное различие между ними, что позволяет отнести их к двум разным уставным традициям.

Ключевые слова: певческий цикл праздника Преображения, Студийский устав, Иерусалимский устав, Стихирарь, стихира, попевка, тайнозамкненные начертания. 
Diablova Kristina, postgraduate student of the history of musicand musical ethnography of the Odessa National A. V. Nezhdanova Academy of Music

Features of the Transfiguration Worship in the east Slavic singing orthodox tradition in the late $X I V$ - the first half of the $X V$ centuries in the context of the church charter changing process

Purpose of the study - on the basis of the analysis of the East Slavic liturgical and singing manuscripts of the late XIV - the first half of the XV centuries to find out evolutionary process of the singing part in the Orthodox Transfiguration worship during the transitional period of the church charter changing (Studit's/Jerusalem). Methodology of the study - reliance on the source-study method with the aim to search the given period sources: paleographic method to refine the codes' dates, to research the ways of their verbal and singing fixation; comparative and textual study of a series of the Transfiguration Feast singing, fixed in East Slavic singing manuscripts. Scientific novelty is in the fact that for the first time the Transfiguration singing cycle in Eastern Slavic tradition is investigated in the context of the Church Charter changing process (the Studit's charter for the Jerusalem charter) on the basis of the complex analysis of the music medieval studies. Conclusion: the investigation of a series of East Slavic medieval codes of the transitional period showed: 1. the difference of the liturgical charters from the singing manuscripts in the specified period; 2. the existence of the two representative singing manuscripts in the first half of the XV century; 3. the analysis of the repertoire, genre and textual aspects of the Feast service showed a considerable difference between them, that allows us to admit the existence of two different charter traditions.

Keywords: singing cycle of the Transfiguration Feast, Studit's charter, Jerusalem charter, stichera, stichera book, popevka, secret tracings.

Дяблова Крістіна Олегівна, аспірантка кафедри історії музики та музичної етнографії ОНМА імені А. В. Нежданової

Особливості служби Преображення у східнослов'янській співочій православній традицї кінця XIV - першої половини XV століть у контексті зміни церковних уставів

Мета дослідження - на основі аналізу богослужбових та співочих рукописних джерел кіния XIV - першої половини XV століть виявити еволюційні процеси співочої частини православної служби Преображення у перехідний період зміни церковних уставів (Студійський/Срусалимський). Методологія дослідження - опора на джерелознавчий метод з метою пошуку джерел вказаного періоду для уточнення датування кодексів, дослідження засобів їх вербальної та співочої фіксації; компаративне та текстологічне вивчення деяких піснеспівів свята Преображення, зафіксованих у східнослов'янських співочих рукописах. Наукова новизна полягає в тому, що вперше співочий цикл Преображення пра- 
вославної східнослов'янської традиції розглядається у контексті зміни Студійського уставу на Єрусалимський на основі комплексного аналізу музичної медієвістики. Висновки. Дослідження деяких східнослов'янських кодексів перехідного часу, знайдених автором роботи, показало: 1. відміну богослужбових уставів від співочих рукописів вказаного періоду; 2. наявність двох репрезентативних співочих джерел першої половини XV століття; 3. аналіз репертуарно-жанрових та текстологічних аспектів служби показав значні відмінності між ними, що дозволяє віднести їх до двох різних уставних традииій.

Ключові слова: співочий иикл свята Преображення, Студійський устав, Срусалимський устав, Стихирарь, стихира, поспівка, тайнозамкненні накреслення.

Актуальность темы исследования обусловлена необходимостью изучения особенностей бытования службы Преображения указанного периода. Данное исследование позволит восполнить недостающие сведения относительно развития певческого цикла праздника, а также предоставит возможность для компаративного анализа с другими православными праздничными циклами соответствующего времени.

Цель исследования - на основе анализа восточнославянских богослужебных и певческих рукописных источников конца XIV - первой половины XV столетия выявить эволюционные процессы певческой части православной службы Преображения в переходный период смены церковных уставов (Студийский/Иерусалимский).

Научная новизна состоит в том, что впервые преображенский певческий цикл православной восточнославянской традиции рассматривается в контексте смены Студийского устава на Иерусалимский на основе комплексного анализа музыкальной медиевистики.

Изложение основного материала. Богослужебная история восточнославянской Православной Церкви, начиная со времени распространения христианства на Руси и вплоть до середины XVII столетия, претерпевала значительные видоизменения. Согласно исследованиям известного современного ученого А. М. Пентковского, в литургической традиции указанной церкви можно выделить три реформы:

I. Реформа преподобного Феодосия Печерского, проводившаяся с благословения церковных властей, результатом которой стал древнерусский перевод Типикона патриарха Алексия Студита и связанный с ним комплекс богослужебных книг. 
II. Реформа митрополитов Московских Алексия и Киприана, в результате чего появился перевод константинопольской редакции Иерусалимского устава и соответствующего комплекса богослужебных книг.

III. Реформа патриархов Никона и Иоакима, в результате которой была создана современная редакция Иерусалимского устава и всего комплекса богослужебных книг [6, 74].

В данной работе в центре нашего внимания оказался период, связанный с процессом перехода от Студийского устава к Иерусалимскому, относящийся к рубежу XIV-XV вв.

Литургические преобразования, проводимые Церковью, коренным образом отразились на церковно-певческом искусстве и повлекли за собой множество трансформаций в этой области. Подтверждением сказанного могут служить многочисленные изменения, наблюдаемые на примере певческого цикла двунадесятого праздника Преображения.

В связи с этим наибольший интерес для нас представляют два крюковых списка - Стихирари первой половины XV столетия (рукописи № 45 Погодинского собрания Российской национальной библиотеки 1422 года и Ф. 304.I № 407 Российской государственной библиотеки 1437 года), в которых ярче всего среди известных нам древнерусских певческих кодексов с песнопениями праздника Преображения отражен процесс смены уставов.

Время создания этих списков разделяет промежуток всего лишь в 15 лет. Однако репертуарно-жанровый и текстологический анализ указанных источников показал существенные различия между ними, что свидетельствует о принадлежности рукописей к различным уставным традициям. Этот факт можно объяснить постепенной сменой Студийского устава на Иерусалимский, осуществлявшейся в этот период. По словам А. Пентковского, «процесс вытеснения Студийско-Алексиевского устава и связанного с ним комплекса богослужебных книг из литургической практики был длительным и продолжался в течение всего XV столетия» $[6,76]$. При этом длительный период параллельного существования двух богослужебных уставов сопровождался бесконфликтным и постепенным переходом от старого устава к новому, что влекло за собой разночтения на различных уровнях певческих списков одного и того же времени.

Обратимся к репертуарно-жанровому составу рассматриваемых Стихирарей. 


\begin{tabular}{|c|c|}
\hline РНБ. Погод. 45 (1422 г.) & РГБ. Ф. 304.I. № 407 (1437 г.) \\
\hline & $\begin{array}{l}\text { Предпразднство } \\
\text { Слава, и ныне на «Господи, воззвах», } \\
\text { глас } 5 \text { (в рукописи все указания } \\
\text { отсутсвуют) }{ }^{1} \text { : } \\
\text { «Прндєтє взыдєм в на горل госпюдьнн» } \\
\text { (л. 196) }\end{array}$ \\
\hline & $\begin{array}{l}\text { Малая вечерня } \\
\text { Слава, и ныне на «Господи, воззвах», } \\
\text { глас } 8 \text { (в рукописи все указания } \\
\text { отсутствуют): } \\
\text { « АНака законьн маго» (л. } 196 \text { об.) }\end{array}$ \\
\hline 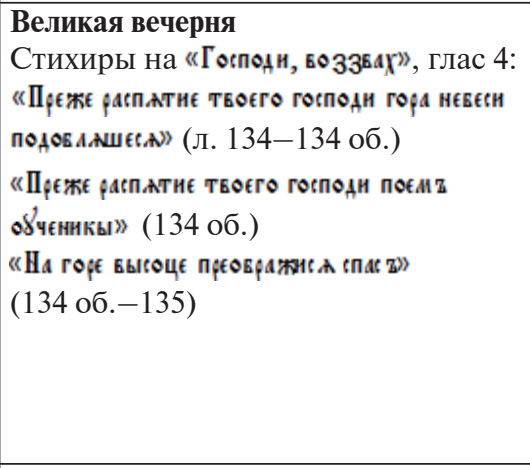 & 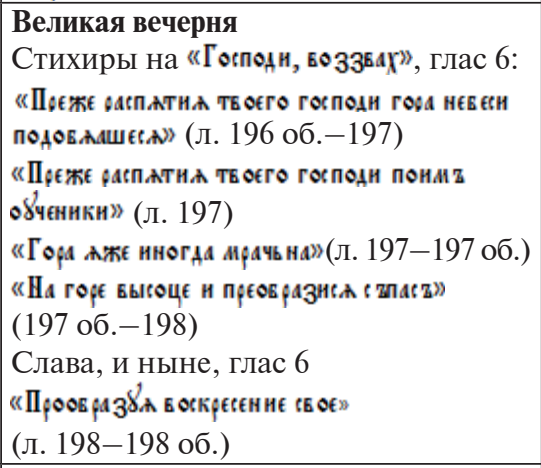 \\
\hline \multirow[t]{2}{*}{ 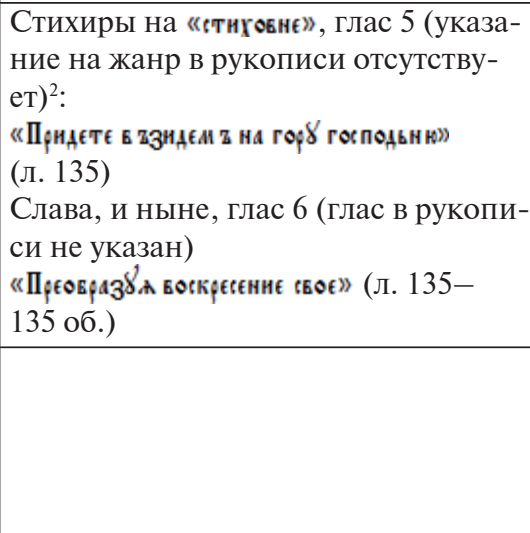 } & 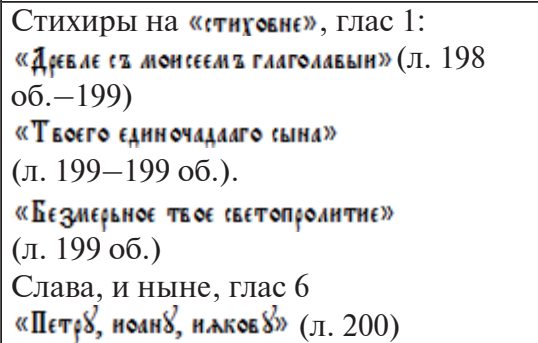 \\
\hline & 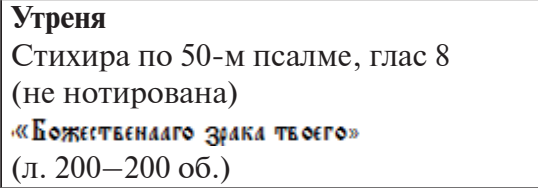 \\
\hline
\end{tabular}

${ }^{1}$ Отсутствующие указания дополнены нами в соответствии с содержанием Иерусалимских Миней XV века (РГБ. Ф. 304.I. № 586. Л. 43-67 об.; № 587. Л. 38-66; № 588. Л. 40 об.-68 об.).

${ }^{2}$ Пробелы данной рукописи восполнены нами по списку Студийского устава (ГИМ. Син. 330. Л. 185 об.). 


\begin{tabular}{|c|c|}
\hline РНБ. Погод. 45 (1422 г.) & РГБ. Ф. 304.І. № 407 (1437 г.) \\
\hline 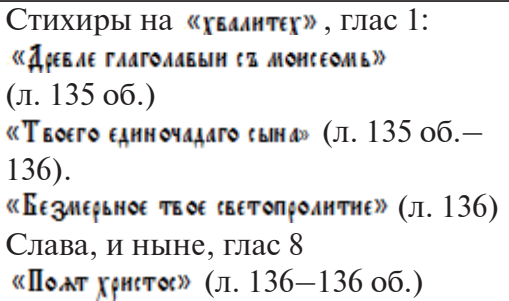 & $\begin{array}{l}\text { Слава, и ныне на «үванттех», глас } 8 \\
\text { «Пожт хрнстос» (л. } 200 \text { об.-201) }\end{array}$ \\
\hline
\end{tabular}

В списке 1422 года зафиксировано 9 песнопений Преображения, среди которых представлены только стихиры. Состав и последовательность песнопений совпадают с указаниями на день праздника Преображения Студийского устава 70-х годов XII века (ГИМ. Син. 330. Л. 185-187 об.) ${ }^{1}$. Этот важнейший фактор дает нам основание отнести данный Стихирарь к Студийской традиции. Единственное отличие Стихираря от устава - это предписания для исполнения стихиры 8-го гласа "Пожт хрнстољ», которую, согласно уставному списку, следует исполнять в первый день попразднства, тогда как в певческой рукописи она выступает в качестве славника на «хвалитех» утрени самого дня праздника. Отметим, что функция заключительного песнопения микроцикла на «хвалитех» для указанного песнопения окончательно закрепляется в уставе Иерусалимской эпохи. Допускаем, что появление стихиры под данным жанровым обозначением в рассматриваемом Студийском Стихираре может говорить о влиянии уже распространившейся к тому времени иерусалимской традиции на Руси.

В Стихираре 1437 года в репертуарно-жанровом аспекте, по сравнению с предыдущим кодексом, наблюдаются значительные изменения. Круг песнопений, посвященных празднику Преображения, расширяется до 13 стихир. В известных нам певческих списках впервые наблюдаем появление двух песнопений - стихиры Малой вечерни «Шірака законьнааго» (л. 196 об.) и ненотированной стихиры по 50-м псалме утрени “Божєетвєнааго зака тв оєго (л. 200-200 об.). Наличие стихиры Малой вечерни르 говорит о принадлежности данного списка к Иерусалимской традиции.

\footnotetext{
${ }^{1}$ Полный текст устава опубликован в одной из работ А. М. Пентковского (см. Пентковский А. М. Типикон патриарха Алексия Студита в Византии и на Руси [7]).

${ }^{2}$ Малая вечерня вошла в литургическую практику вместе с принятием Иерусалимского устава $[8,480 ; 5,74]$.
} 
Как видно из сравнительной репертуарно-жанровой таблицы двух Стихирарей, ряд песнопений в более поздней рукописи меняет свою литургическую функцию:

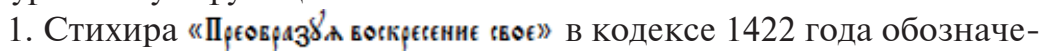
на как славник на «стиховне» Великой вечерни, а в рукописи 1437 года становится заключительным песнопением на «Господи, воззвах»;

2. Рядовые стихиры микроцикла на «хвалитех» утрени перемещаются в микроцикл на «стиховне» Великой вечерни;

3. ПесноПение «Пондетє в взндем в на гоя господьн ю»" ${ }^{1}$, выступая стихирой на «стиховне» в раннем списке, в более позднем источнике зафиксирована как одна из стихир предпразднства.

Все вышеописанные изменения соответствуют переменам в области уставной и минейной традиций.

Стихирарь 1437 года предстает как наиболее ранний из известных нам певческих списков, где микроцикл стихир на «Господи, воззвах» представлен пятью песнопениями, сохраняющими указанную последовательность и в современной службе. Среди них - четыре самоглас-

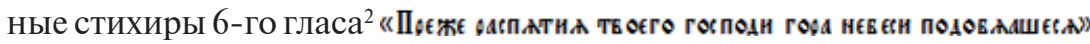
(Л. 196 об.-197), «Прежє распатна тв оєго господн понм з о४ченики» (Л. 197), «Гора жже иногда мрачьна» (Л. 197-197 об.) «На горе высоце и прєевразисл с тпасъ» (л. 197 об.-198) и славник 6-го гласа «Проовраз ४.а воскрєєєниє єь оє» 6-Го гласа (л. 198-198 об.). Известно, Что песнопения «Гора ажє иногда мрачь на»

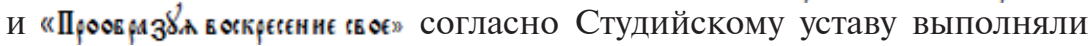
иные литургические функции. Первое из них исполнялось в первый день попразднества в качестве славника на «Господи, воззвах», а второе являлось славником стихир на стиховне (см. ГИМ. Син. 330. Л. $185-186$ об.).

Таким образом, анализ репертуарно-жанрового состава рассматриваемых кодексов позволяет предположить, что Стихирарь по-

\footnotetext{
${ }^{1}$ Данное песнопение, согласно Иерусалимскому уставу, наряду с функцией стихиры предпразднества, исполняется также в микроцикле стихир на «литии» Великой вечерни. Стихиры на «литии», как и Малая вечерня, появились в чинопоследовании после перехода на Иерусалимский устав. Однако в рассматриваемом иерусалимском Стихираре 1437 года стихиры на «литии» не представлены.

${ }^{2}$ Указанный источник является единственным в нашем каталоге, где за рядовыми стихирами на «Господи, воззвах» Великой вечерни закреплен 6-й глас. Согласно всем известным нам уставным, минейным и певческим кодексам данные песнопения следует исполнять на 4-й глас. В связи с этим можно предположить, что в данном Стихираре писцом была допущена ошибка.
} 
годинского собрания является одной из последних певческих рукописей Студийской эпохи, тогда как Стихирарь РГБ предстает как наиболее ранний нотированный кодекс Иерусалимской традиции.

Отметим при этом, что лишь жанрово-репертуарный аспект списка РГБ в полной мере соответствует Иерусалимскому уставу.

Во-первых, его поэтический текст представлен древней истинноречной фонетической редакцией, типичной для Студийской эпохи.

Во-вторых, текстологический анализ песнопений праздника Преображения из кодекса РГБпоказал наличие в нем певческихзнаков, сохранившихся от древней нотации XI-XIV веков. Среди них: чашка $J$,

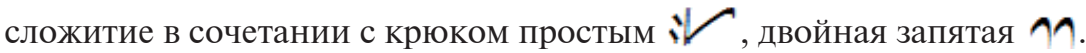
Причем в некоторых случаях применяются несколько двойных запятых подряд. Самый яркий пример - первая стихира на «Господи, воз-

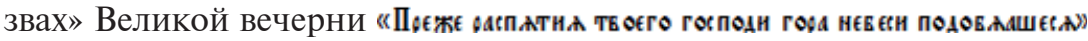
(л. 196 об.-197), где в окончании второй, третей и четвертой строк рифмование поэтического текста сопровождается включением двойных запятых в крюковой строке, что создает вербально-певческую эпифору ${ }^{1}$.

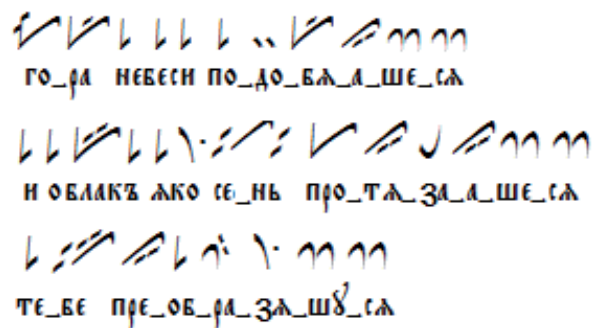

Таким образом, Стихирарь 1437 года нельзя однозначно рассматривать как исключительно образец Иерусалимского типикона. Скорее он представляет певческую рукопись переходного времени от Студийского к Иерусалимскому уставу.

Обратимся к сравнительному текстологическому анализу рассматриваемых Стихирарей. Рассмотрение текстологических параметров этих списков демонстрирует их принадлежность к различным типам редакций. Сходства наблюдаются лишь в области кадансирования

1 3. Гусейнова, исследуя по рукописям Кирилло-Белозерского монастыря знаменную нотацию XV века, в одном из источников второй половины XV столетия (Кир.Бел. 654/911. Л. 175 об.) в славнике на «хвалитех» праздника Преображения обнаружила последовательность четырех двойных запятых подряд [3, 68]. 
(отнюдь не всегда), отдельных знамен (в основном стопиц) и некоторых тайнозамкненных начертаний.

В качестве примера рассмотрим музыкально-поэтический текст стихиры 1-го гласа "Т воєго єднночадаго сын . Деление текста в рассматриваемых Стихирарях осуществляется различно. В первом кодексе знаками высокой точки отмечено15 вербально-певческих колонов, во втором - 13 .

В певческой строке первой рукописи (см. пример 1) представлен силлабический тип напева с преобладанием стопиц L. Отметим использование графических анафор и эпифор: так 8 строк из 15 начинаются крюком мрачным простой статьей ; (2-5-я; 7-я; 11-я) и 2- статьей закрытой (8-9-я).

\section{Пример 1}

РНБ, Погод. 45 (л. 135 об. -136)

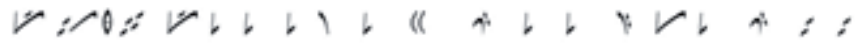

1. TEO_f_RO 6_AH_HO_Yа_Aа_О

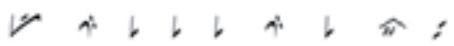

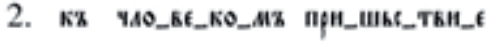

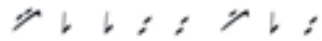

3. 50_rO_O_Th_ЦL AA_EM_A3

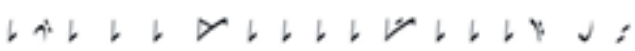

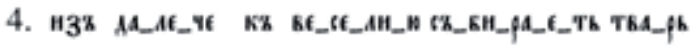

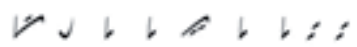

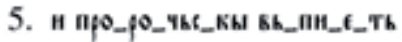

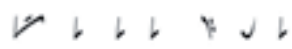

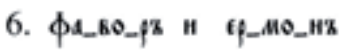

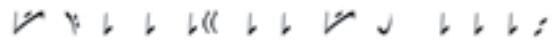

7.

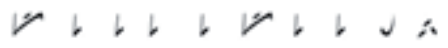

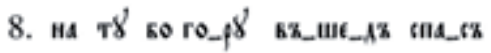




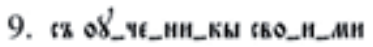

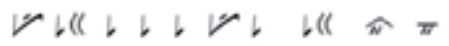

10. OMLP_yEH_O_E ALAAL_AE ETT_TTEO

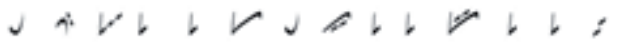

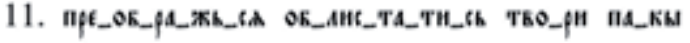

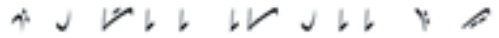

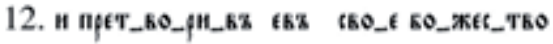

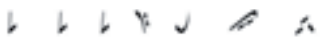

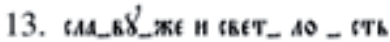

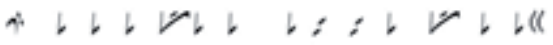

14. TE_Mь 50_IIH_E_M

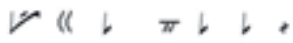

15. rOt_nO_Al CAA_EA TO_Ef.

Крюковый текст второго списка (см. пример 2) усложнен по сравнению с первым: количество стопиц существенно сокращается, в окончании некоторых строк последовательность отдельных знамен напоминает попевки (например, 2-ю и 6-ю строки завер-

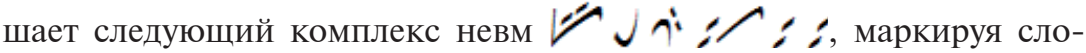

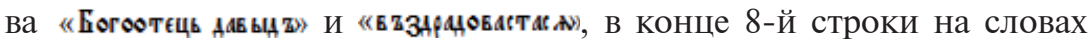
"aдaмaє єетєтьо" применяется видоизмененный вариант этого ком-

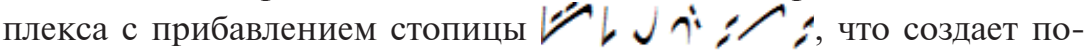
вторение в певческой строке), а в завершении 4-й строки нам удалось обнаружить попевку «мережа»

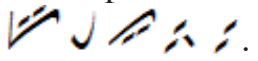

Что касается тайнозамкненных начертаний, то в рассматриваемых кодексах их функционирование также различно. Совпадает месторасположение только одной фиты, которая поставлена распевщиком в начале песнопения, подчеркивая первое слово стихиры - «Тв єго, где гимнограф обращается к Богу-Отцу. Во втором списке находим еще две фиты: первая из них распевает глагол «взывыєт, повествуя о ветхозаветном пророке, царе и псалмопевце Давиде, приглашающем все человечество к торжеству и прославлению будущего Мессии. В певческой строке фите предшествует явление, названное М. Браж- 
никовым, «разбегом» стопиц. В данном случае перед фитой расположено пять стопиц, значение которых, по мнению исследователя, заключается в речитативной подготовке перед сложным мелизматическим распевом [1, 145-146].

Распеваемый глагол предшествует прямой цитате из 88-го псалма Давида “Фавор н єрмон о нмєнн твоєм возяад самым усиливая значимость цитируемого материала в гимнографической ткани стихиры. Третья фита песнопения маркирует глагол «пєетворнв», в котором высказывается важная с духовной точки зрения идея об искуплении грехов мира через страдания Иисусом Христом как Богочеловека, что преобразило "очєрнєвшє адамово єє тевє тво", КаК поется в стихире, превратив его в божественную светлость и славу.

Отметим, что на протяжении песнопения трижды применяется одна и та же фита - «Поводная» $/$ $\theta:$, которая, по замечанию М. Бражникова, чрезвычайно распространена в песнопениях 1-го гласа. Существуют два варианта начертаний данной фиты, распевы которых очень единообразны: со знаком змеицы после фиты

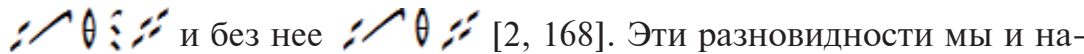
ходим в анализируемой стихире, что видно в примере 2:

\section{Пример 2}

PTE, ф. 304. I. Ne 407 ( J. 199-199 o6.)

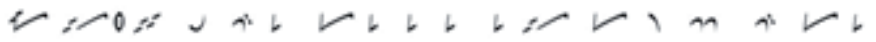

1. Tkо_f

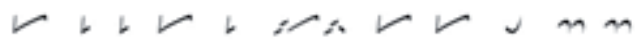

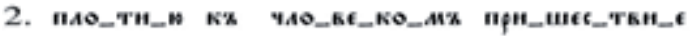

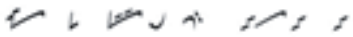

3. 5O_rO_O_T6_ML AA_Eh_-AT

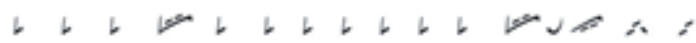

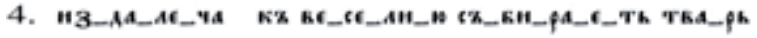

$\checkmark a b b b \quad b=10 \xi$

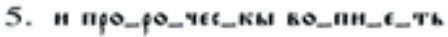

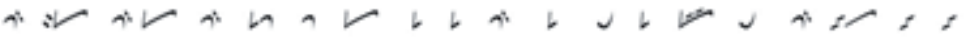

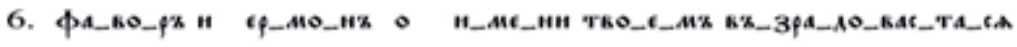

mank

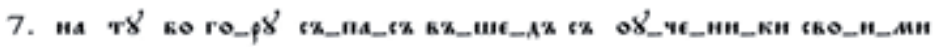

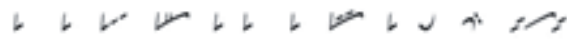




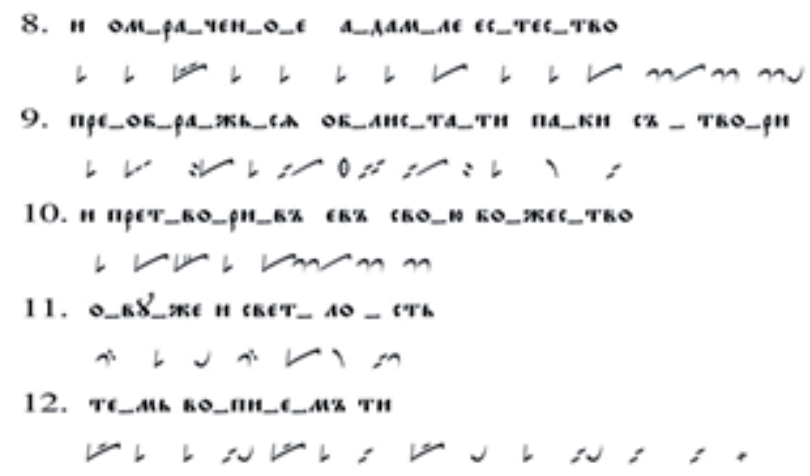

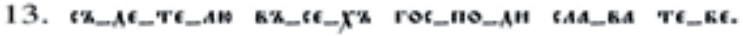

В рукописи РНБ на местах второй и третьей фит кодекса РГБ расположены единогласостепенные знамена (крюк $/$, чашка $J$, стопица $l$, статья \{) . Отметим, что список 1422 года является единственной исследованной нами певческой рукописью, в которой глаголЫ «взываєт» И «прєтворнв» фитами не сопровождаются, что представляет своего рода исключение, поскольку для песнопений праздника Преображения, как и для всего древнерусского певческого искусства в целом, характерна четкая закрепленность фитных начертаний за определенными фрагментами вербального текста $[1,64 ; 4,55]^{1}$.

Выводы. Длительный процесс смены уставов на Руси (Студийского на Иерусалимский), занявший почти целое столетие (с конца XIV и практически весь XV век) - это время существенных изменений в богослужебной истории православной Церкви, в том числе и церковно-певческой традиции. Исследовав репертуарно-жанровые и текстологические аспекты песнопений праздника Преображения двух Стихирарей первой половины XV столетия, время создания которых разделяет всего лишь пятнадцатилетний промежуток (что по меркам средневекового церковно-певческого искусства представляет незначительный временной отрезок), мы можем говорить о принад-

${ }^{1}$ В данном источнике отсутствие указанных фит - не единственный случай отличий в фиксации фитных комплексов по сравнению с другими певческими кодексами. В славнике на «хвалитех» 8-го гласа «Поят Христос» здесь встречаются две фиты, в то время как во всех остальных изученных нами рукописях фит в этом песнопении нет. На этот факт также обращает внимание О. Шангина, исследуя песнопения праздника Преображения, в том числе на материале рукописей, не попавших пока в поле нашего научного обозрения $[9,141]$. 
лежности первого анализируемого списка всецело Студийской эпохе и, возможно, он является одним из последних ее представителей, имеющем специфику расположения фитных комплексов. Второй памятник представляет собой один из первых примеров певческой рукописной традиции переходного этапа от Студийского устава к Иерусалимскому, что продемонстрировано, прежде всего, особенностями его репертуарно-жанрового состава.

\section{СПИСОК ЛИТЕРАТУРЫ}

1. Бражников М. Древнерусская теория музыки. По рукописным материалам XV-XVIII веков. Л.: Музыка, 1972. 423 с.

2. Бражников М. Лица и фиты знаменного распева. Л.: Музыка, 1984. $303 \mathrm{c}$.

3. Гусейнова 3. Знаменная нотация XV века (по рукописям Кирилло-Белозерского монастыря). Древнерусское песнопение. Пути во времени. СПб. : Из-во политехн. ун-та, 2010. Вып. 4. С. 67-77.

4. Кравченко С. Фиты знаменного роспева (на материале певческой книги «Праздники»: дис. ... канд. искусствоведения: спец. 17.00.02. Л., 1981. $193 \mathrm{c}$.

5. Красовицкая М. Литургика. М.: Православный Свято-Тихоновский богословский институт, 2007. 304 с.

6. Пентковский А. Литургические реформы в истории Русской Церкви и их характерные особенности. Журнал Московской Патриархии. М., 2001. № 2. C. $72-80$.

7. Пентковский А. Типикон патриарха Алексия Студита в Византии и на Руси. М.: Изд-во Моск. Патриархии, 2001. 432 с.

8. Скабалланович М. Толковый типикон. Объяснительное изложение Типикона с историческим введением. М.: Сретенский монастырь, 2004. $816 \mathrm{c}$.

9. Шангина О. Песнопения на «Слава, и ныне» в чинопоследовании Преображения Господня. Источники. Текстология. Поэтика. (На материале русских нотированных рукописей XII - начала XVIII веков): дипломная работа. СПб., 2013. 189 с.

\section{REFERENCES}

1. Brazhnikov M. (1972). Old Russian theory of music. On handwritten materials of XV-XVIII centuries. Leningrad: Muzyika [in Russian].

2. Brazhnikov M. (1984). Litsa i thetas of znamenny singing. Leningrad: Muzyika [in Russian].

3. Guseynova Z. (2010). Notation of znamenny singing XV century (by manuscripts of Cyrillo-Belozersky monastery). Drevnerusskoe pesnopenie. Puti vo vremeni, P. 67-77. Sankt-Peterburg: Iz-vo Politekhn. un-ta [in Russian]. 
4. Kravchenko S. (1981). Thetas of znamenny singing (by material of singing book «Prazdniki». Candidate's thesis. Leningrad [in Russian].

5. Krasovitskaya M. (2007). Liturgics. Moskva: Pravoslavnyy Svyato-Tikhonovskiy Bogoslovskiy Institut [in Russian].

6. PentkovskiyA. (2001). Liturgical reforms in the history of the Russian Church and their characteristics. Zhurnal Moskovskoy Patriarkhii, P. 72-80. Moskva: Moskovskaya patriarkhiya [in Russian].

7. Pentkovskiy A. (2001). The Patriarch Alexy Studit's Typicon in Byzantium and Old Russia. Moskva: Moskovskaya patriarkhiya [in Russian].

8. Skaballanovich M. (2004). Explanatory Typicon. Moskva:Sretenskiy monastyr [in Russian].

9. Shangina, O. (2013). Chants of «Slava, i nyne» in the order of the Transfiguration. Sources. The text. Poetics (by material of russian notated manuscripts XIIXVIII centuries). Sankt-Peterburg [in Russian].

Стаття надійила до редакції 20.12.2017

УДК 788.5

DOI $10.31723 / 2524-0447-2018-26-148-160$

Лукацька Ганна Олександрівна

https://orcid.org/0000-0002-2320-3842

концертмейстер кафедри концертмейстерства

Одеської національної музичної академії імені А. В. Нежданової

sukhanova-anna@mail.ru

\title{
ОСОБЛИВОСТІ СТАНОВЛЕННЯ ФЛЕЙТИ ЯК АНСАМБЛЕВОГО ІНСТРУМЕНТА У ФРАНЦУЗЬКІЙ МУЗИЦІ НА МЕЖІ ХІХ-ХХ СТОЛІТЬ
}

\begin{abstract}
Мета статті - виявити основні фактори становлення франиузької камерної музики на межі ХІХ-ХХ століть, які впливали на розвиток флейти як ансамблевого інструмента. Методологія. Дослідження спирається на музично-історичний і музично-культурологічний підходи, що дають можливість виявлення тих подій, фактів і обставин побутування франиузької камерно-інструментальної музики, які стимулювали активний розвиток флейти в якості учасника камерного ансамблю. Наукова новизна полягає у дослідженні розвитку флейти як ансамблевого інструмента у франиузькій музичній культурі на межі ХIX-XX cm. - того історичного періоду, який часто вважають «золотим століттям» флейти. Розквіт виконавського мистецтва, а також активний інтерес композиторів Франції до иього інструмента сприяли створенню нового ансамблевого репертуару для флейти, який роз-
\end{abstract}

(C) Лукацька Л. Г., 2018 